Article

\title{
The Role of Root Exudates of Barley Colonized by Pseudomonas fluorescens in Enhancing Root Colonization by Fusarium culmorum
}

\author{
Nadezhda Vishnevskaya ${ }^{1}$, Vlada Shakhnazarova ${ }^{1,2}$, Alexander Shaposhnikov ${ }^{1}$ and \\ Olga Strunnikova ${ }^{1, *}$ \\ 1 All-Russia Research Institute for Agricultural Microbiology, Podbelsky shosse 3, 196608 St \\ Petersburg-Pushkin, Russia; navishnevskaya@rambler.ru (N.V.); shahnazarova-v@mail.ru (V.S.); \\ ai-shaposhnikov@mail.ru (A.S.) \\ 2 Department of Agrochemistry, Saint Petersburg State University, 16 Liniya V.O. 29, 199178 St Petersburg, \\ Russia \\ * Correspondence: olgastrunnikova@rambler.ru
}

Received: 18 February 2020; Accepted: 14 March 2020; Published: 16 March 2020

\begin{abstract}
The aim of this study was to find out why after joint inoculation of the substrate with the phytopathogenic fungus Fusarium culmorum and the antagonistic bacterium Pseudomonas fluorescens the amount of the fungus on the root surface in the beginning of the colonization was greater on the roots colonized by the bacterium than on control roots. This phenomenon is especially interesting because joint inoculation with $P$. fluorescens was always followed by a considerable decrease in the incidence of Fusarium root rot. In two experiments barley was grown in sterile vermiculite inoculated only with F. culmorum, only with P. fluorescens and jointly with the fungus and the bacterium. In the control, vermiculite was not inoculated with any microorganisms. After the removal from the vermiculite, barley plants were transferred into deionized water for the collection of root exudates. The duration of barley growth in the vermiculite and in the water was different in the two experiments. The exudates were tested for their ability to elicit chemotropism in F. culmorum and influence its growth. We did not observe any chemotropism of F. culmorum towards barley root exudates. However, the exudates of the barley colonized by the bacterium stimulated the growth of fungal germ tubes. Using an ultra-performance liquid chromatography system, we found that experimental conditions influenced the quantitative composition of the exudates. The amount of amino acids in the solution of exudates decreased considerably after a prolonged growth of control barley in water, while the presence of $P$. fluorescens resulted in a considerably increase of the amount of amino acids in the exudates. The exudates of barley colonized by $P$. fluorescens contained much more glucose, lactic acid and several amino acids than the exudates of control barley. These components are known to be necessary for the growth of F. culmorum. Their presence in the exudates of barley colonized by $P$. fluorescens seems to be the reason of a more active colonization by the fungus of barley roots colonized by the bacterium.
\end{abstract}

Keywords: plant-microbe interactions; root exudates; chemotropism; colonization; growth stimulation of germ tubes

\section{Introduction}

Fusarium culmorum (W. G. Smith) Saccardo is a common facultative phytopathogenic fungus affecting numerous crops [1]. In grain crops, it causes seedling blight, root rot, foot rot and Fusarium head blight, which may be expressed at all stages of plant development and result in a considerable loss of yield [2-7]. The grain of infected crops accumulates trichothecine toxins hazardous to humans 
and animals [8-10]. In eukaryotic cells, these toxins inhibit the synthesis of proteins, DNA and RNA, change the membrane structure and affect cell division and apoptosis [11,12].

Plant diseases caused by soilborne fungi can be controlled with the use of rhizobacteria. [13-16]. One such rhizobacterium with biocontrol properties is Pseudomonas fluorescens strain 2137. In our earlier studies P. fluorescens strain 2137 actively suppressed the development of F. culmorum 30 both in the soil without plants and in the barley rhizosphere $[17,18]$. At the same time, we noted that after joint inoculation of the substrate with F. culmorum and P. fluorescens the amount of the fungus on the root surface in the beginning of barley colonization was greater than in case of inoculation with the fungus only [18-20]. Later the amount of F. culmorum on barley roots varied considerably both after inoculation with the fungus only and after inoculation with the fungus and the bacterium together. However, an increased amount of F. culmorum on the root surface in the first days of colonization in case of joint inoculation with P. fluorescens was always followed by a considerable decrease in the incidence of Fusarium root rot [18-20].

It is unclear what makes F. culmorum actively colonize the roots in the presence of P. fluorescens. An answer to this question would elucidate the earliest stages of interactions between the plant, the fungus and the bacterium and establish the role of the plant in these interactions. Information about the causes of the increased amount of the pathogen on the roots in the presence of its antagonist accompanied by a biocontrol effect is an essential step in the study of biocontrol mechanisms.

A more active colonization could be associated with a chemotropic response of the fungus. While the response of rhizosphere bacteria to plant root exudates has often been shown [21-26], that of soil fungi is less well studied. Both tomato roots and root exudates induced a significant chemotropic response in Fusarium oxysporum $\mathrm{f}$. sp. lycopersici microconidia [27]. Exudates of tomato growing in a split-root system and stressed with wounding or salt stimulated the growth especially well, acting as attractants of the biocontrol fungus Trichoderma harzianum T22. At the same time, such exudates did not enhance chemotropism in the phytopathogenic fungus Fusarium oxysporum f. sp. lycopersici, as compared with exudates of unstressed plants. The authors suggested that some biocontrol microorganisms might have developed an ability to sense a broader range of stress signals than plant pathogens [28].

The aim of this study was to find out why the amount of F. culmorum on the roots of barley colonized by P. fluorescens increases at the early stage of colonization. We hypothesized that the root exudates of barley colonized by the bacterium induced a chemotropic response in F. culmorum, possibly because the bacterium affected the composition of the exudates and/or some of its own metabolites were added to the exudates. To check our hypothesis, we tested the chemotropism of F. culmorum to the root exudates of control barley and the barley colonized by the bacterium and assessed their effect on fungal growth. In order to find out whether the exudates contained substances with a potential positive effect on F. culmorum, we performed a comparative analysis of sugars, organic acids and amino acids in the exudates.

\section{Results}

2.1. The Effect of Experimental Conditions on the Amount of F. culmorum and P. fluorescens in the Roots and Root Rot Incidence in Barley Plants

The amount of F. culmorum on the root surface in the presence of P. fluorescens increased very early in the process of fungal colonization. Therefore, for the study of this phenomenon we needed the exudates of young barley plants. We performed two experiments specially designed in such a way as to find out whether the composition and the amount of the exudates depended on growth conditions and the duration of exudation.

The microorganisms and the barley seeds were added to the vermiculite and incubated in potted cultures for $36 \mathrm{~h}$ in experiment 2 and for $67 \mathrm{~h}$ in experiment 1 . Earlier experiments showed that $36 \mathrm{~h}$ was a sufficient time for the fungus and the bacterium inoculated into the vermiculite to establish in the rhizosphere and colonize barley roots. Increasing the time to $67 \mathrm{~h}$ allowed the pathogen, the 
antagonist and the plant to develop close interactions in the rhizosphere, which might have affected the intensity of root colonization and the composition of the root exudates.

In both experiments plants taken out of the vermiculite for the collection of root exudates were transferred into deionized water and kept there for $24 \mathrm{~h}$ in experiment 1 and for $96 \mathrm{~h}$ in experiment 2 . The amount of the fungus and the bacterium in the roots was determined after barley growth in the vermiculite. The number of plants with root rot symptoms was assessed in the end of the experiments. In experiment 2, we also assessed the amount of the fungus and the bacterium in the solution of exudates and their amount in 132-h-old barley roots in the end of the experiment (Table 1).

F. culmorum and P. fluorescens inoculated into the vermiculite colonized barley roots in both experiments. In the experiment with inoculation by the fungus only, its amount was greater in the roots growing in the vermiculite for $36 \mathrm{~h}$ (experiment 2 ) than in those growing for $67 \mathrm{~h}$ (experiment 1 ); the number of plants with root rot symptoms was the same in both experiments (Table 1). The amount of P. fluorescens in the roots in case of inoculation of the vermiculite with the bacterium only was also higher in 36-h-old barley (experiment 2). In case of joint inoculation of the vermiculite with the fungus and the bacterium, the amount of the fungus in the roots increased considerably while the amount of the bacterium, on the contrary, decreased considerably as compared with the inoculation by the fungus and the bacterium separately. At the same time, the joint inoculation with F. culmorum and P. fluorescens resulted in a decrease in the number of plants with root rot symptoms in both experiments (Table 1).

In experiment 2, the amount of the fungus and the bacterium in barley roots decreased after 96 hours of growth in water. However, in this experiment, too, the simultaneous presence of F. culmorum and P. fluorescens in the roots resulted not only in an increased amount of the fungus but also in a decreased amount of the bacterium. During $96 \mathrm{~h}$ of barley growth in the water, F. culmorum and $P$. fluorescens were also present in the solution of the exudates. The amount of bacterium in the solution was greater than that of the fungus (Table 1). 
Table 1. Barley disease incidence and the amount of Fusarium culmorum and Pseudomonas fluorescens in the roots and in water.

\begin{tabular}{|c|c|c|c|c|c|c|c|c|}
\hline \multirow{3}{*}{ Conditions of the Experiment } & \multirow{3}{*}{$\begin{array}{l}\text { Vermiculite } \\
\text { Inoculation }\end{array}$} & \multirow{3}{*}{$\begin{array}{l}\text { Diseased } \\
\text { Plants (\%) }\end{array}$} & \multicolumn{3}{|c|}{ Amount of the Fungus after the Growth of Barley } & \multicolumn{3}{|c|}{ Amount of the Bacterium after the Growth of Barley } \\
\hline & & & \multirow{2}{*}{$\begin{array}{l}\text { in the Vermiculite } \\
\text { CFU/g of Root }\left(10^{3}\right)\end{array}$} & \multicolumn{2}{|c|}{ In Water } & \multirow{2}{*}{$\begin{array}{l}\text { In the Vermiculite } \\
\text { CFU/g of Root }\left(10^{5}\right)\end{array}$} & \multicolumn{2}{|c|}{ In Water } \\
\hline & & & & CFU/g of Root $\left(10^{3}\right)$ & $\mathrm{CFU} / \mathrm{mL}\left(\mathbf{1 0}^{2}\right)$ & & CFU/g of Root $\left(10^{5}\right)$ & $\mathrm{CFU} / \mathrm{mL}\left(10^{3}\right)$ \\
\hline \multirow{4}{*}{$\begin{array}{l}\text { Experiment 1: } \\
\text { The growth of barley in the vermiculite - } \\
67 \mathrm{~h} \text {, the exudation in water - } 24 \mathrm{~h} \text {. The } \\
\text { age of barley at the end of the } \\
\text { experiment - } 91 \mathrm{~h}\end{array}$} & None & 0 & & & & & & \\
\hline & F. culmorum & 16 & $1.2 \pm 0.3 \mathrm{a}$ & & & & & \\
\hline & P. fluorescens & 0 & & & & $95.7 \pm 5 \mathrm{a}$ & & \\
\hline & $\begin{array}{l}\text { F. culmorum }+P \text {. } \\
\text { fluorescens }\end{array}$ & 8 & $29 \pm 10 \mathrm{~b}$ & & & $48.7 \pm 14 \mathrm{~b}$ & & \\
\hline \multirow{3}{*}{$\begin{array}{l}\text { Experiment 2: } \\
\text { The growth of barley in the vermiculite - } \\
36 \mathrm{~h} \text {, the exudation in water - } 96 \mathrm{~h} \text {. The } \\
\text { age of barley at the end of the } \\
\text { experiment }-132 \mathrm{~h}\end{array}$} & None & 0 & & & & & & \\
\hline & F. culmorum & 16 & $19.9 \pm 3 \mathrm{a}$ & $11.7 \pm 3.6 \mathrm{c}$ & $0.5 \pm 0.05 \mathrm{a}$ & & & \\
\hline & $\begin{array}{l}\text { P. fluorescens } \\
\text { F. culmorum }+P \text {. }\end{array}$ & $\begin{array}{c}0 \\
10\end{array}$ & $158.9 \pm 35 \mathrm{~b}$ & $40.3 \pm 6 \mathrm{~d}$ & $3,3 \pm 1 \mathrm{~b}$ & $\begin{array}{c}221.9 \pm 63 a \\
90,7 \pm 27 c\end{array}$ & $\begin{array}{l}83.3 \pm 25 c \\
46.7 \pm 11 b\end{array}$ & $\begin{array}{c}15 \pm 2 \mathrm{a} \\
12,3 \pm 1,8 \mathrm{a}\end{array}$ \\
\hline
\end{tabular}

Values in the same experiment with different letters are significantly different at $p \leq 0.05$ when applying Fisher's LSD test. Values are means \pm standard deviations. 


\subsection{Testing the Chemotropic Response in F. culmorum Towards Barley Root Exudates}

Root exudates collected in the two experiments were tested for their ability to elicit chemotropic response in F. culmorum. Microscopic examination showed that approximately the same number of germ tubes were oriented towards wells with exudates and wells with water (Figure 1). We found no differences in the number of germ tubes growing towards exudates of control barley and exudates of roots colonized by $P$. fluorescens.

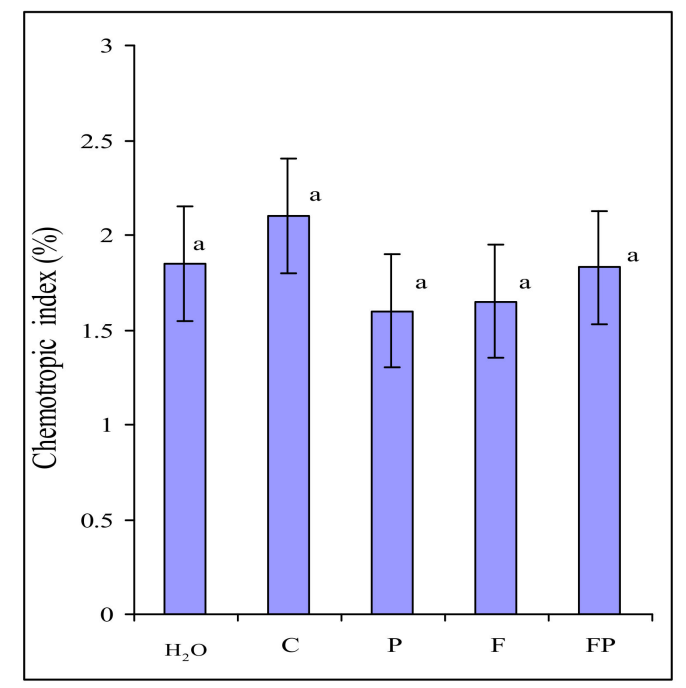

Figure 1. Directed growth of Fusarium culmorum macroconidia germ tubes to water $\left(\mathrm{H}_{2} \mathrm{O}\right)$ and to exudates of: control barley (C), barley colonized by Pseudomonas fluorescens (P), barley colonized by F. culmorum (F), barley colonized by both P. fluorescens and F. culmorum (FP). Data are presented as the mean from two experiments. $n=600$ germ tubes. Error bars show standard deviation. Values of different letters are significantly different at $p \leq 0.05$ when applying Fisher's LSD test.

\subsection{Influence of Root Exudates on the Growth of F. culmorum}

In order to find out why F. culmorum actively colonized barley roots with P. fluorescens, we also assessed the influence of root exudates collected in the two experiments on the fungal growth (Figure 2). Microscopic examination showed that the proportion of germinated macroconidia of F. culmorum was the same in the experiments with their incubation in the exudates of control barley, the exudates of barley inoculated with the fungus and the bacterium, in Czapek-Dox broth (CDB) and in water. However, the growth of germ tubes was considerably stimulated after incubation of

F. culmorum macroconidia in the exudates of barley colonized by the bacterium as compared with the exudates of control barley (Figure 2). Incubation in the exudates of control barley and the exudates of barley colonized by the fungus influenced the length of the germ tubes in the same manner. The germ tubes were somewhat shorter in the experiment with incubation of macroconidia in the exudates of the roots colonized jointly by the fungus and the bacterium (Figure 2).

It would seem that these results are easy to explain by the influence of the nutrition available to the fungus, as evidenced by its minimum development in water and maximum development in $\mathrm{CDB}$. However, a greater length of germ tubes in the exudates of barley colonized by the bacterium as compared with the control barley exudates apparently indicates that the exudates of barley colonized by $P$. fluorescens contained substances stimulating fungal growth. 


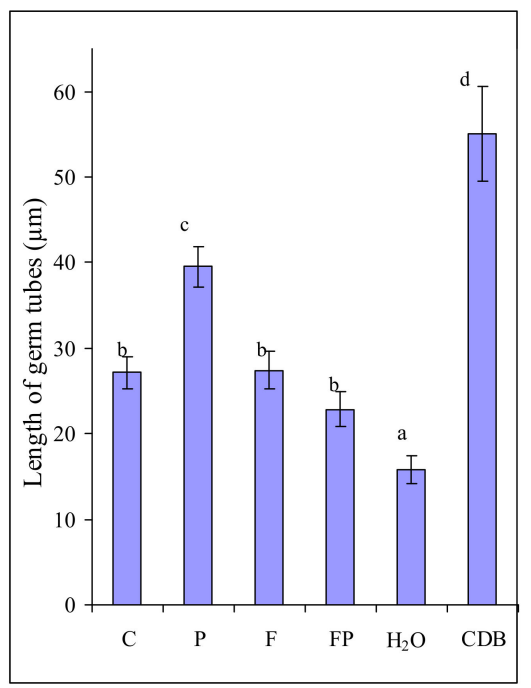

Figure 2. Length of germ tubes of Fusarium culmorum macroconidia after $6 \mathrm{~h}$ of incubation in solutions of exudates of control barley (C), barley colonized by P. fluorescens (P), barley colonized by F. culmorum (F) and barley colonized by both P. fluorescens and F. culmorum (FP), in sterile water $\left(\mathrm{H}_{2} \mathrm{O}\right)$, in liquid medium (CDB). Data are presented as the mean from two experiments. $n=300$ macroconidia. Error bars show standard deviation. Values of different letters are significantly different at $p \leq 0.05$ when applying Fisher's LSD test.

\subsection{The Effect of P. fluorescens on the Growth of F. culmorum}

In order to check whether the bacterium itself could stimulate the growth of the fungus, we assessed the influence of $P$. fluorescens on the germination of F. culmorum macroconidia. Fungal macroconidia and bacterial cells were suspended in a mineral solution and kept for $6 \mathrm{~h}$ to ensure their interaction. In control, fungal macroconidia were incubated in a mineral solution without the bacterium. P. fluorescens considerably inhibited the germination of macroconidia (Figure 3A) and suppressed fungal growth (Figure 3B).
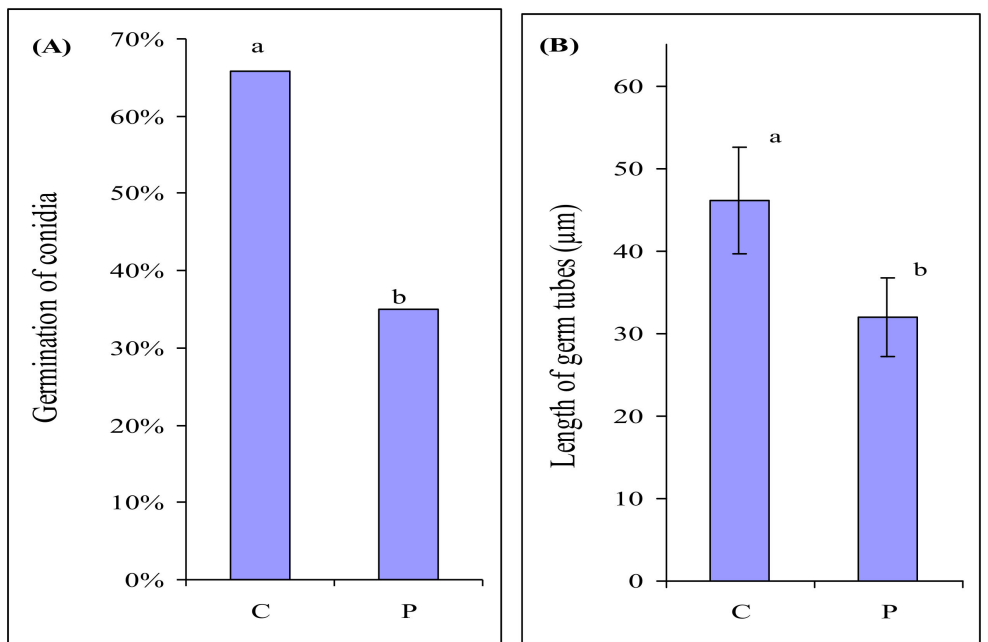

Figure 3. Germination of Fusarium culmorum macroconidia (A), length of germ tubes of F. culmorum macroconidia (B) after $6 \mathrm{~h}$ of incubation in the mineral medium in the absence (C) and presence of P. fluorescens (P). $n=300$ macroconidia. Significant differences in germination of macroconidia were analyzed using Mann-Whitney U-test. Error bars show standard deviation. Values of different letters are significantly different at $p \leq 0.05$ when applying Fisher's LSD test, and at $p \leq 0.01$ when applying Mann-Whitney U-test. 
2.5. Quantitative Composition of Sugars, Organic Acids and Amino Acids in Root Exudates of Control Barley, Barley Colonized by P. fluorescens and Jointly by F. culmorum + P. fluorescens

Our results showed that $P$. fluorescens did not stimulate the growth of F. culmorum but, on the contrary, suppressed it. However, root exudates of barley colonized by the bacterium stimulated early stages of fungal growth. We hypothesized that the stimulation might be associated with the presence of nutrients necessary for fungal growth in the root exudates.

We identified the substances utilized by F. culmorum and P. fluorescens by comparing the amount of initial and residual components after five days of their growth in the solution of barley root exudates in a previous study [29]. The results are summarized in Table 2 (only the substances utilized most actively by the fungus during its growth are given). We found that the fungus and the bacterium mostly used sugars, especially glucose. P. fluorescens utilized organic acids and amino acids more actively than $F$. culmorum. Glucose was the preferable source of carbon for the growth of F. culmorum.

Table 2. Components of barley root exudates consumed by Fusarium culmorum and Pseudomonas fluorescens during 5 days of growth in the exudate solution. (Based on the results of earlier studies [29]).

\begin{tabular}{|c|c|c|c|}
\hline \multirow{2}{*}{ Components of Barley Root Exudates } & \multirow{2}{*}{ Initial Amount ( $\mu \mathrm{g} / \mathrm{mL})$} & \multicolumn{2}{|c|}{ Amount $(\mu \mathrm{g} / \mathrm{mL})$ Consumed by } \\
\hline & & F. culmorum & P. fluorescens \\
\hline \multicolumn{4}{|l|}{ Sugars: } \\
\hline glucose & $357.6 \pm 68$ & $328.8 \pm 59 a$ & $240 \pm 23.5 b$ \\
\hline fructose & $34.7 \pm 7.3$ & $16.8 \pm 3.8 \mathrm{a}$ & $24.5 \pm 4.7 \mathrm{a}$ \\
\hline other & $147.1 \pm 20.7$ & $1.1 \pm 0.2 \mathrm{a}$ & $1 \pm 0.1 \mathrm{a}$ \\
\hline \multicolumn{4}{|l|}{ Organic acids: } \\
\hline malic & $11.7 \pm 2.1$ & $6 \pm 1.3 \mathrm{a}$ & $9.2 \pm 2 \mathrm{a}$ \\
\hline lactic & $9 \pm 1.6$ & $8 \pm 1.9 \mathrm{a}$ & $7.7 \pm 1.4 \mathrm{a}$ \\
\hline other & $14.8 \pm 2.8$ & $0.1 \pm 0.01 \mathrm{a}$ & $11 \pm 3.3 b$ \\
\hline \multicolumn{4}{|l|}{ Amino acids: } \\
\hline proline & $1.75 \pm 0.22$ & $0.9 \pm 0.2 \mathrm{a}$ & $0.4 \pm 0.06 \mathrm{~b}$ \\
\hline phenylalanine & $1.2 \pm 0.2$ & $0.8 \pm 0.1 \mathrm{a}$ & $1.1 \pm 0.2 b$ \\
\hline tryptophan & $0.85 \pm 0.2$ & $0.75 \pm 0.08 \mathrm{a}$ & $0.8 \pm 0.09 b$ \\
\hline histidine & $0.55 \pm 0.13$ & $0.33 \pm 0.09 \mathrm{a}$ & $0.47 \pm 0.14 \mathrm{a}$ \\
\hline tyrosine & $0.45 \pm 0.11$ & $0.32 \pm 0.1 \mathrm{a}$ & $0.4 \pm 0.11 \mathrm{a}$ \\
\hline valine & $0.57 \pm 0.12$ & $0.39 \pm 0.1 \mathrm{a}$ & $0.5 \pm 0.1 \mathrm{a}$ \\
\hline lysine & $0.35 \pm 0.1$ & $0.15 \pm 0.05 \mathrm{a}$ & $0.32 \pm 0.07 b$ \\
\hline leucine & $0.69 \pm 0.17$ & $0.35 \pm 0.09 \mathrm{a}$ & $0.67 \pm 0.12 b$ \\
\hline isoleucine & $0.42 \pm 0.13$ & $0.19 \pm 0.04 \mathrm{a}$ & $0.4 \pm 0.08 b$ \\
\hline other & $2.08 \pm 0.25$ & $0.35 \pm 0.1 \mathrm{a}$ & $1.47 \pm 0.2 \mathrm{~b}$ \\
\hline
\end{tabular}

Values with different letters are significantly different at $p \leq 0.05$ when applying Fisher's LSD test. Values are means \pm standard deviations.

In order to reveal the components potentially enhancing the growth of F. culmorum, we performed a comparative analysis of the amount of sugars, organic acids and amino acids in the root exudates of barley collected in the two experiments.

The comparative analysis showed that the content of sugars was considerably higher in the exudates of barley colonized by the bacterium than in control barley exudates, mostly because of a considerable increase in the glucose level (Table 3). In exudates of control barley and barley colonized by the bacterium (experiment 2) the content of sugars was lower than in exudates in experiment 1 
(Table 3). However, in this experiment, too, the level of glucose in the exudates of barley colonized by the bacterium was statistically significantly higher than in the control barley exudates.

Table 3. Amount of sugars in the exudates of control barley colonized by P. fluorescens and jointly by $F$. culmorum $+P$. fluorescens collected in the two experiments.

\begin{tabular}{|c|c|c|c|c|c|c|}
\hline \multirow{3}{*}{ Sugars } & \multicolumn{6}{|c|}{ Amount of Sugars $(\mu \mathrm{g} / \mathrm{g}$ DW) in the Absence and Presence of Microbes } \\
\hline & \multicolumn{3}{|c|}{ Experiment 1} & \multicolumn{3}{|c|}{ Experiment 2} \\
\hline & None & $\begin{array}{c}P . \\
\text { fluorescens }\end{array}$ & $\begin{array}{c}\text { F. culmorum } \\
+P . \\
\text { fluorescens }\end{array}$ & None & $\begin{array}{c}P . \\
\text { fluorescens }\end{array}$ & $\begin{array}{c}\text { F. culmorum } \\
+P . \\
\text { fluorescens }\end{array}$ \\
\hline Melibiose & $62 \pm 14 \mathrm{a}$ & $29.5 \pm 15 b$ & $22 \pm 9 b$ & ND & ND & ND \\
\hline Maltose & $2968 \pm 590 \mathrm{a}$ & $3500 \pm 350 \mathrm{a}$ & $492 \pm 190 \mathrm{~b}$ & $736 \pm 244 a$ & $658 \pm 151 \mathrm{a}$ & $286 \pm 83 b$ \\
\hline Sucrose & $21 \pm 10 \mathrm{a}$ & $60 \pm 30 \mathrm{ab}$ & $9.5 \pm 5$ ac & $62 \pm 29$ a & $2 \pm 1.1 \mathrm{~b}$ & $2.7 \pm 1.2 \mathrm{~b}$ \\
\hline Glucose & $1800 \pm 485 \mathrm{a}$ & $4500 \pm 845 b$ & $1346 \pm 497 \mathrm{a}$ & $122.5 \pm 27 \mathrm{a}$ & $490 \pm 152 b$ & $67 \pm 31 \mathrm{a}$ \\
\hline Fructose & $140 \pm 30 a$ & $210 \pm 100 \mathrm{a}$ & $133 \pm 40 \mathrm{a}$ & $132 \pm 37 \mathrm{a}$ & $32 \pm 23 b$ & $21 \pm 6 b$ \\
\hline Arabinose & $729 \pm 195 \mathrm{a}$ & $359 \pm 39 b$ & $104 \pm 28 c$ & $141 \pm 43 \mathrm{a}$ & $167 \pm 79 a$ & $89 \pm 41 a$ \\
\hline Xylose & $51 \pm 9 a$ & $161 \pm 27 b$ & $84 \pm 28 a$ & $31 \pm 9 a$ & $81 \pm 19 b$ & $13 \pm 7 c$ \\
\hline Ribose & $199 \pm 49 a$ & $127 \pm 14 b$ & $150 \pm 48 \mathrm{ab}$ & $144 \pm 58 a$ & $133 \pm 72 a$ & $87 \pm 37 a$ \\
\hline
\end{tabular}

Values in the same experiment with different letters are significantly different at $p \leq 0.05$ when applying Fisher's LSD test. Values are means \pm standard deviations. ND $=$ not detected. Substances most actively utilized by $F$. culmorum are marked in bold.

The amount of sugars in the exudates of barley colonized jointly by the fungus and the bacterium collected in both experiments was lower than in the exudates of control barley and barley colonized only by the bacterium. This was due to an active utilization of sugars by both microorganisms in barley roots and in the solution of root exudates. A decreased amount of glucose in the exudates in the presence of $P$. fluorescens noted in experiment 2 could be associated with a decrease in the total amount of sugars as well as by the utilization of glucose by the bacterium itself, which was present in the roots and in the solution of exudates during the $96 \mathrm{~h}$ of barley growth in water (Table 1).

In exudates collected in experiment 1 the total content of organic acids in the exudates of barley colonized by the bacterium was somewhat lower than in those of control barley (Table 4). However, the amount of propionic acid and lactic acid was higher in the exudates of barley colonized by the bacterium than in the control barley exudates. F. culmorum did not utilize propionic acid but actively utilized lactic acid (Table 2). The amount of propionic acid also increased in the exudates of barley jointly colonized by the fungus and the bacterium. In the exudates of barley colonized by the bacterium collected in experiment 2 the composition of dominating acids changed: the levels of succinic and, especially, acetic acid increased (Table 4). An increased amount of some organic acids in the exudates of barley roots colonized by $P$. fluorescens may be associated with the metabolism of the bacterium itself. A decreased amount of organic acids in the exudates of barley colonized by jointly the fungus and the bacterium can be explained by the fact that the microorganisms utilized these substances during their growth.

The amount of amino acids in the exudates of barley collected in experiment 1 was higher in the exudates of control barley than in the exudates of barley colonized by the bacterium (Table 5). Obviously, amino acids as the source of nitrogen were used by P. fluorescens for its growth. The exudates of control barley collected in experiment 2 contained a much lesser amount of all amino acids except $\gamma$-aminobutyric acid, the amount of which increased. On the contrary, in the exudates of barley colonized by the bacterium the amount of most amino acids increased considerably (Table 5). Some of these amino acids were essential for the growth of F. culmorum (Table 2). 
Table 4. Amount of organic acids in the exudates of control barley colonized by P. fluorescens and of barley jointly colonized by F. culmorum and P. fluorescens collected in the two experiments.

\begin{tabular}{|c|c|c|c|c|c|c|}
\hline \multirow{3}{*}{$\begin{array}{l}\text { Organic } \\
\text { Acids }\end{array}$} & \multicolumn{6}{|c|}{ Amount of Organic Acids ( $\mu \mathrm{g} / \mathrm{g}$ DW) in the Absence and Presence of Microbes } \\
\hline & \multicolumn{3}{|c|}{ Experiment 1} & \multicolumn{3}{|c|}{ Experiment 2} \\
\hline & None & $\begin{array}{c}P . \\
\text { fluorescens }\end{array}$ & $\begin{array}{c}\text { F. culmorum } \\
+P . \\
\text { fluorescens }\end{array}$ & None & P. fluorescens & $\begin{array}{c}\text { F. culmorum }+P \text {. } \\
\text { fluorescens }\end{array}$ \\
\hline Pyroglutamic & $12 \pm 2 \mathrm{a}$ & $4 \pm 2 b$ & $0.7 \pm 0.3 c$ & $18 \pm 1$ & ND & ND \\
\hline Propionic & $523 \pm 46$ a & $2100 \pm 298 b$ & $1980 \pm 280 b$ & $74 \pm 36 \mathrm{a}$ & ND & $188 \pm 86 \mathrm{a}$ \\
\hline Fumaric & $11 \pm 5 a$ & $1.4 \pm 0.5 b$ & $2.5 \pm 0.6 \mathrm{~b}$ & $0.7 \pm 0.3 \mathrm{a}$ & $0.3 \pm 0.13 a$ & ND \\
\hline Acetic & $1673 \pm 344 \mathrm{a}$ & $912 \pm 45 b$ & $919 \pm 108 b$ & $1654 \pm 334 a$ & $7865 \pm 1320 b$ & $2184 \pm 832 a$ \\
\hline Lactic & $284 \pm 76 a$ & $579 \pm 128 b$ & $340 \pm 78 \mathrm{a}$ & $196 \pm 10 \mathrm{a}$ & $45 \pm 8 b$ & $37 \pm 14 b$ \\
\hline Succinic & $935 \pm 229 a$ & $60 \pm 19 b$ & $132 \pm 52 c$ & $1363 \pm 341 a$ & $1173 \pm 296 a$ & $295 \pm 91 b$ \\
\hline t-Aconitic & $15 \pm 3 a$ & $10 \pm 1 b$ & $6 \pm 0.8 c$ & $210 \pm 7 a$ & $49 \pm 18 b$ & $2.6 \pm 1.3 c$ \\
\hline Malic & $1400 \pm 298 a$ & $290 \pm 82 b$ & $312 \pm 97 b$ & $198 \pm 21 \mathrm{a}$ & $120 \pm 6 b$ & ND \\
\hline Pyruvic & $169 \pm 33 a$ & $81 \pm 15 b$ & $52 \pm 11 c$ & $68 \pm 4.5 a$ & $79 \pm 13 a$ & $33 \pm 6 b$ \\
\hline Citric & $25 \pm 3 a$ & $6 \pm 0.8 b$ & $6 \pm 0.8 b$ & $309 \pm 93 a$ & $166 \pm 48 b$ & $2.2 \pm 0.5 c$ \\
\hline Oxalic & $65 \pm 14 a$ & $38 \pm 8 \mathrm{ab}$ & $25 \pm 7 b$ & ND & ND & ND \\
\hline
\end{tabular}

Values in the same experiment with different letters are significantly different at $p \leq 0.05$ when applying Fisher's LSD test. Values are means \pm standard deviations. $\mathrm{ND}=$ not detected. Substances most actively utilized by $F$. culmorum are marked in bold.

Table 5. The amount of amino acids in exudates of control barley, barley colonized by P. fluorescens and barley jointly colonized by F. culmorum and P. fluorescens collected in the two experiments.

\begin{tabular}{|c|c|c|c|c|c|c|}
\hline \multirow{3}{*}{ Amino acids } & \multicolumn{6}{|c|}{ Amount of amino acids ( $\mu \mathrm{g} / \mathrm{g} \mathrm{DW})$ in the absence and presence of microbes } \\
\hline & \multicolumn{3}{|c|}{ Experiment 1} & \multicolumn{3}{|c|}{ Experiment 2} \\
\hline & None & $\begin{array}{c}P . \\
\text { fluorescens }\end{array}$ & $\begin{array}{c}\text { F. culmorum+ } P \text {. } \\
\text { fluorescens }\end{array}$ & None & $\begin{array}{c}P . \\
\text { fluorescens }\end{array}$ & $\begin{array}{c}\text { F. culmorum }+P \text {. } \\
\text { fluorescens }\end{array}$ \\
\hline Phenylalanine & $36 \pm 1.8 \mathrm{a}$ & $21 \pm 2.6 \mathrm{~b}$ & $4 \pm 0.5 \mathrm{c}$ & $2.8 \pm 0.2 \mathrm{a}$ & $17 \pm 1.3 \mathrm{~b}$ & $5.4 \pm 0.1 \mathrm{c}$ \\
\hline Leucine & $42 \pm 4.5 \mathrm{a}$ & $17 \pm 1.8 \mathrm{~b}$ & $10 \pm 2 c$ & $7.5 \pm 0.2 \mathrm{a}$ & $45 \pm 2 b$ & $6 \pm 0.2 \mathrm{a}$ \\
\hline Isoleucine & $27 \pm 1 \mathrm{a}$ & $10 \pm 1.3 \mathrm{~b}$ & $7 \pm 0.8 \mathrm{~b}$ & $1.9 \pm 0.1 \mathrm{a}$ & $34 \pm 3 b$ & $1.9 \pm 0.1 \mathrm{a}$ \\
\hline Lysine & $25 \pm 5 a$ & $12 \pm 1.6 \mathrm{~b}$ & $9 \pm 1.1 b$ & $8 \pm 0.2 \mathrm{a}$ & $50 \pm 2.5 b$ & $4 \pm 0.1 c$ \\
\hline Ornitine & $3 \pm 0.9 a$ & $0.8 \pm 0.2 \mathrm{~b}$ & $0.6 \pm 0.1 \mathrm{~b}$ & $0.25 \pm 0.1 \mathrm{a}$ & $0.5 \pm 0.15 a$ & $0.6 \pm 0.15 a$ \\
\hline Methionine & $4.3 \pm 0.9 \mathrm{a}$ & $1.7 \pm 0.6 \mathrm{~b}$ & $0.7 \pm 0.2 \mathrm{c}$ & $0.9 \pm 0.1 \mathrm{a}$ & $4.5 \pm 0.38 b$ & $1 \pm 0.1 \mathrm{a}$ \\
\hline Valine & $38 \pm 6 a$ & $14 \pm 2.6 \mathrm{~b}$ & $7 \pm 1.3 c$ & $8 \pm 0.3 a$ & $70 \pm 3.5 b$ & $3 \pm 0.2 c$ \\
\hline Tyrosine & $23 \pm 1.5 \mathrm{a}$ & $10 \pm 1.1 \mathrm{~b}$ & $3.2 \pm 0.5 c$ & $2.5 \pm 0.2 \mathrm{a}$ & $23 \pm 1.1 b$ & $1.2 \pm 0.1 \mathrm{c}$ \\
\hline Cysteine & $3 \pm 0.3 \mathrm{a}$ & $6.5 \pm 0.9 b$ & $1.2 \pm 0.5 \mathrm{a}$ & $4 \pm 0.2 .3 \mathrm{a}$ & $0.5 \pm 0.1 b$ & $4 \pm 1.9 \mathrm{a}$ \\
\hline $\begin{array}{c}\gamma \text {-Aminobutyric } \\
\text { acid }\end{array}$ & $75 \pm 8 a$ & $7.2 \pm 1.4 b$ & $7.6 \pm 1.5 b$ & $290 \pm 45 a$ & $130 \pm 21 b$ & $2 \pm 0.1 c$ \\
\hline Proline & $129 \pm 18 \mathrm{a}$ & $43 \pm 9 b$ & $16.5 \pm 3.5 c$ & $44 \pm 7 \mathrm{a}$ & $8.5 \pm 0.4 b$ & $6 \pm 0.2 c$ \\
\hline Alanine & $41 \pm 11 \mathrm{a}$ & $29 \pm 7 \mathrm{a}$ & $28 \pm 5 a$ & $20 \pm 1 \mathrm{a}$ & $23 \pm 1 \mathrm{a}$ & $7.2 \pm 0.4 b$ \\
\hline Threonine & $7.2 \pm 0.8 \mathrm{a}$ & $3.5 \pm 0.6 \mathrm{~b}$ & $3.5 \pm 0.5 b$ & $0.8 \pm 0.2 \mathrm{a}$ & $2.4 \pm 0.8 \mathrm{a}$ & $0.8 \pm 0.2 \mathrm{a}$ \\
\hline Arginine & $14 \pm 2.8 \mathrm{a}$ & $7.3 \pm 0.6 \mathrm{~b}$ & $0.4 \pm 0.1 \mathrm{c}$ & $3 \pm 0.3 a$ & $8 \pm 0.5 b$ & $8.5 \pm 0.4 b$ \\
\hline Histidine & $6 \pm 0.9 a$ & $5.4 \pm 0.9 \mathrm{a}$ & $3.9 \pm 0.6 \mathrm{a}$ & $19 \pm 0.8 \mathrm{a}$ & $24.5 \pm 1 b$ & $3.6 \pm 0.4 \mathrm{c}$ \\
\hline Glycine & $20 \pm 4.5 \mathrm{a}$ & $16 \pm 3.8 \mathrm{a}$ & $9.5 \pm 2 c$ & $1.5 \pm 0.1 \mathrm{a}$ & $21 \pm 2 b$ & $3 \pm 0.3 c$ \\
\hline Glutamic acid & $130 \pm 24 a$ & $64 \pm 7 b$ & $82 \pm 12 c$ & $4 \pm 0.25 a$ & $12 \pm 1.1 \mathrm{~b}$ & $5 \pm 0.4 \mathrm{a}$ \\
\hline Serine & $45 \pm 11 \mathrm{a}$ & $19 \pm 4 b$ & $12 \pm 3 b$ & $22 \pm 1.5 \mathrm{a}$ & $84 \pm 3 b$ & $3 \pm 0.2 c$ \\
\hline Aspartic acid & $66 \pm 11 \mathrm{a}$ & $15 \pm 3 b$ & $39 \pm 9 c$ & $5 \pm 0.2 \mathrm{a}$ & $39 \pm 2.5 b$ & $3 \pm 0.1 c$ \\
\hline Tryptophane & $20 \pm 6 a$ & $19.5 \pm 5 a$ & $2.4 \pm 0.7 b$ & $0.7 \pm 0.1 \mathrm{a}$ & $9 \pm 0.4 b$ & $3 \pm 0.2 c$ \\
\hline
\end{tabular}

Values in the same experiment with different letters are significantly different at $p \leq 0.05$ when applying Fisher's LSD test. Values are means \pm standard deviations. Substances most actively utilized by F. culmorum are marked in bold. 
In root exudates of barley colonized by the fungus and the bacterium, the amount of all amino acids decreased dramatically in experiment 2 , in which the amino acids from the exudate solution were utilized not only by the bacterium but also by the fungus, and possibly by the plant itself.

\section{Discussion}

In our experiments, joint inoculation of the vermiculite with F. culmorum and P. fluorescens resulted in an increased amount of the fungus on the barley roots as compared with the inoculation of the substrate with the fungus only (Table 1). This phenomenon has also been observed in our previous studies. The elucidation of its causes was the aim of this research.

We ascertained that an increased amount of F. culmorum on the roots was not associated with its chemotropism towards the exudates of barley colonized by P. fluorescens (Figure 1). In our experiments, the amount of macroconidia germ tubes oriented towards exudates and towards water was approximately the same. In the present study, we did not register any influence of root exudates and $\mathrm{CDB}$ on the germination of F. culmorum macroconidia and the chemotropism of germ tubes, contrary to what has been noted in F. oxysporum [27]. The reason behind this difference may be that in F. culmorum the germination and an initial stage of germ tube growth are less dependent on the exogenous nutrition than in F. oxysporum. Large macroconidia of F. culmorum can provide the growing hypha with nutrients for a longer time that small microconidia of F. oxysporum. However, the growth rate of F. culmorum macroconidia germ tubes did depend on the exogenous nutrition. This explains the increased length of the germ tubes after the incubation of macroconidia in the root exudates of barley colonized by the bacterium (Figure 2), which contain many more components necessary for the fungal growth than the control barley exudates (Tables 3-5). The dependence of the germination level on the size of the fungal structure has also been shown for Fusarium oxysporum f. sp. lycopersici. The germination rate of its microconidia in root exudates of tomato differed greatly, and did not exceed $50 \%-60 \%$, whereas the germination level of chlamydospores was the same in different exudates, reaching $100 \%$ [30].

However, the root exudates of barley colonized by the bacterium stimulated the growth of macroconidia germ tubes while the root exudates of control barley did not (Figure 2). It has been shown that the germination of F. oxysporum $\mathrm{f}$. sp. lycopersici microconidia is stimulated by tomato root exudates [31-33]. The root exudates from transgenic insect-resistant cotton significantly promote the spore germination and mycelial growth of cotton F. oxysporum [34]. In our experiments, however, the growth of F. culmorum macroconidia germ tubes was more strongly stimulated by the root exudates of barley colonized by P. fluorescens than by the other root exudates (Figure 2). The greatest stimulation effect was observed during incubation of macroconidia in CDB (Figure 2). CDB contains much more carbohydrates than root exudates and does not contains any substances toxic for the fungus. On the contrary, barley root exudates contain aromatic carboxylic acids (ACA), which have antimicrobial properties. Earlier we showed that ACA suppressed the growth of F. culmorum [35].

The fact that we did not reveal any chemotropism of F. culmorum to exudates indicates that the exudates of barley colonized by the bacterium do not contain any components that can attract the fungus to the roots. However, we observed the stimulation of the fungal growth by root exudates of barley colonized by the bacterium. In the absence of attractants, growth (and thus a more intensive colonization of the roots) may be stimulated by additional nutrition. This was supported by the results of stimulation of the fungal growth during its incubation in the nutrient medium (Figure 2). We analyzed sugars, organic acids and amino acids, because they are known to be essential for the growth of the rhizosphere microorganisms [36-38].

Comparative analysis showed that the exudates of barley colonized by the bacterium contained more components necessary for the fungal growth than the control barley exudates (Tables 3-5). Our analysis showed that the root exudates of barley colonized by P. fluorescens contained the highest amounts of glucose (Table 3), an increased amount of lactic acid (Table 4) and significantly greater amounts of phenylalanine, tryptophan and other amino acids than the control barley exudates (Table 5). 
It is possible that in this study and in our earlier experiments the exudates of barley colonized by $P$. fluorescens stimulated not only the growth of germ tubes of $F$. culmorum macroconidia but also further growth of its mycelium. This stimulation could lead to a more active colonization by the fungus of the roots colonized by the bacterium than sterile (control) roots.

Joint inoculation of the vermiculite with the pathogen and its antagonist resulted in a greater amount of F. culmorum but a lesser amount of P. fluorescens in barley roots as compared to the mono-inoculation (Table 1). We have already demonstrated that F. culmorum 30 and P. fluorescens 2137 jointly inoculated into the vermiculite successfully colonized the roots and occupied almost the same root zones $[19,39]$. When both microorganisms were present on the root surface, the amount of each could later fluctuate and, in particular, decrease significantly. However, regardless of the fluctuations of the abundance of $P$. fluorescens on the root surface, its presence always resulted in a decrease in the number of diseased barley plants [18-20]. Apparently, the final outcome (the disease incidence in barley) was determined not by the amount of the phytopathogenic fungus and/or antagonistic bacterium in the roots but by their functional activity. Our further studies will focus on the mechanisms of interactions between F. culmorum, P. fluorescens and barley plants.

We noted a considerable effect of conditions on the quantitative composition of barley exudates in our experiments. The exudates collected in experiment 2 , after $96 \mathrm{~h}$ of barley growth in water, contained a lesser amount of sugars, organic acids and especially amino acids than barley exudates collected after $24 \mathrm{~h}$ of growth in experiment 1 . In experiment 2 the plants, kept in deionized water for a long time, could photosynthesize but were actually starving. Under these conditions they probably used some components of their own root exudates, first of all, amino acids. A recapture of root exudates by the plant is an established fact [40-42].

Interestingly, in experiment 2, when the amount of amino acids in the exudates of control barley decreased considerably, it was the presence of $P$. fluorescens in the roots that promoted an increase of their amount in the exudates. It was known that 2,4-diacetylphloroglucinol, commonly produced by rhizosphere pseudomonads, enhances exudation of 16 amino acids from the roots of alfalfa, maize, and wheat [43]. In our study, however, an increased amount of amino acids in the presence of the bacterium was noted only in the exudates collected in experiment 2 (Table 5). In experiment 1 , the presence of the bacterium in barley roots even resulted in a decreased amount of amino acids in the exudates as compared to the control. These data indicate that environmental conditions may be a crucial factor influencing the interactions between barley and the biocontrol bacterium $P$. fluorescens.

The experiment showed that $P$. fluorescens itself had no stimulating effect whatever on F. culmorum. It demonstrated an evident antagonistic effect on the fungus (Figure 3). Thus, the stimulation of $F$. culmorum growth by root exudates of barley colonized by the bacterium was associated not with the direct effect of the bacterium itself but with its presence in the roots. Apparently, P. fluorescens colonizing the roots influences the composition of root exudates and possibly also adds its own metabolites, which makes the exudates attractive for F. culmorum.

\section{Materials and methods}

\subsection{Study Objects}

We used barley Hordeum vulgare L. cv. Belogorsky, which is susceptible to Fusarium root rot, from the Collection of N.I. Vavilov All-Russian Institute of Plant Genetic Resources. Facultative phytopathogenic fungus Fusarium culmorum strain 30 isolated from barley roots was grown on Czapek-Dox agar (CDA) for 14 days. Macroconidia were washed off with sterile water, precipitated by centrifuging at $11000 \mathrm{rpm}$ for $15 \mathrm{~min}$ at $4{ }^{\circ} \mathrm{C}$, resuspended and brought to the required concentration. An antagonistic bacterium Pseudomonas fluorescens strain 2137 was grown for $24 \mathrm{~h}$ on King's medium B agar at $28{ }^{\circ} \mathrm{C}$ [44]. The cells were suspended in sterile distilled water, precipitated by centrifuging at $10,000 \mathrm{rpm}$ for $15 \mathrm{~min}$ at $4{ }^{\circ} \mathrm{C}$ and resuspended. 


\subsection{Experimental Conditions}

Root exudates of sterile barley and barley colonized by F. culmorum and P. fluorescens were obtained in two experiments. Both were conducted under sterile conditions in airtight glass pots with a volume of $0.5 \mathrm{~L}$, each containing $24 \mathrm{~g}$ of dry vermiculite. In both experiments the vermiculite was inoculated: (1) with a suspension of fungal macroconidia $\left(2 \times 10^{5} / \mathrm{mL}\right),(2)$ a suspension of bacterial cells $\left(1.5 \times 10^{7}\right)$, (3) a suspension of fungal and bacterial cells taken in the same concentrations. Vermiculite in the control pots was not inoculated. The total amount of water, including the suspensions of fungal and bacterial cells, was $250 \mathrm{~mL}$ per each $100 \mathrm{~g}$ of dry vermiculite. Four pots were used in each experiment except the experiment with joint inoculation of the vermiculite with the fungus and the bacterium, when eight pots were used. Barley seeds were sterilized for $30 \mathrm{~s}$ in $96 \%$ ethanol, washed thrice in sterile water and soaked for $30 \mathrm{~min}$ in $1 \%$ solution of $\mathrm{AgNO}_{3}$. After the removal of the silver nitrate, the seeds were washed once in $1 \%$ solution of $\mathrm{NaCl}$ and five times in sterile water. The seeds were transferred into sterile Petri dishes with moist filter paper and kept for $48 \mathrm{~h}$. Germinated seeds were transferred into prepared pots with vermiculite, 10 seeds per pot. Barley plants were grown for $67 \mathrm{~h}$ in experiment 1 and for $36 \mathrm{~h}$ in experiment 2 . After that, they were carefully removed from the pots. Excessive vermiculite was removed by washing the roots in sterile water. One plant from each pot was used to determine the amount of the fungus and the bacterium in barley roots by inoculating homogenized roots on CDA and on King's medium, correspondingly. The remaining plants were transferred into prepared airtight glass pots with sterile deionized water in such a way that the water should cover only the roots. The pots were kept in daylight for $24 \mathrm{~h}$ in experiment 1 and for four days in experiment 2. After that, the solutions of root exudates were centrifuged at $11,000 \mathrm{rpm}$ for $15 \mathrm{~min}$ at $4{ }^{\circ} \mathrm{C}$ for precipitation of fungal cells, bacterial cells and root cells. The supernatants were stored at $-20{ }^{\circ} \mathrm{C}$ until the determination of the composition of root exudates. The roots were examined for the presence of rot symptoms, dried and weighed.

\subsection{Testing the Chemotropism of F. culmorum Towards Barley Exudates}

Chemotropism in F. culmorum was tested with the use of a technique suggested by Turrà et al. [13] with slight modifications. Macroconidia obtained from a 14-day-old fungal culture grown on CDA were washed off the agar with sterile cold $\left(+4^{\circ} \mathrm{C}\right)$ water. They were centrifuged twice $(15 \mathrm{~min}, 11,000 \mathrm{rpm}$, $+4{ }^{\circ} \mathrm{C}$ ) and resuspended in cold water in order to remove CDA residues. A suspension of fungal macroconidia $\left(10^{5} / \mathrm{mL}\right)$ in a volume of $5 \mathrm{~mL}$ was mixed with $5 \mathrm{~mL}$ of warm $1 \%$ water agarose (Serva). The mixture was poured into a Petri dish, $8.5 \mathrm{~cm}$ in diameter, with an inserted template. Once the agarose solidified, the template made it possible to make in it two parallel wells, $77 \times 2 \mathrm{~mm}$ in size, located at a distance of $10 \mathrm{~mm}$ from each other. One of the wells was filled with $200 \mu \mathrm{l}$ of the solution of exudates. The other well was filled with $200 \mu \mathrm{L}$ of sterile water. The Petri dish was incubated at $20{ }^{\circ} \mathrm{C}$. After $13 \mathrm{~h}$ of incubation, a line was drawn on the bottom of the dish between the wells, and the gel layer above it was examined under a microscope (Imager A 1, Zeiss Axio, $200 \times$ magnification). The germ tubes growing towards the well with the exudates and those growing towards the well with water were counted. Three Petri dishes were used in each case, and the growth direction of 200 macroconidium germ tubes was assessed in each dish. The chemotropic index was calculated as $(($ Htest $-\mathrm{Hsw}) /$ Htotal $\times 100)$, where Htest is the number of maroconidia germ tubes growing towards the test exudates, Hsw is the number of germ tubes growing towards the sterile water, and Htotal is the total number of germ tubes counted. For each test compound a total of 600 germ tubes were scored. All experiments were performed twice. Statistical analysis was conducted using $t$-test.

\subsection{Assessment of the influence of barley root exudates on the growth of F. culmorum}

The fungal suspension washed off the medium $\left(2 \cdot 10^{5}\right.$ macroconidia/mL $)$ was mixed with each of the solutions of exudates obtained in two experiments in the proportion of 1:3. For fungal growth control, the suspension of macroconidia was mixed with water (in one case) and CDB (in another case) 
in the same proportions. Macroconidia were incubated for $6 \mathrm{~h}$ at $24{ }^{\circ} \mathrm{C}$. In each case 300 macroconidia of F. culmorum were assesed. The proportion of germinated macroconidia to the total number of examined macroconidia and the length of germ tubes were registered.

\subsection{Assessing the Effect of P. fluorescens on the Growth of F. culmorum}

Fungal macroconidia washed off the medium were diluted with a mineral medium $\left(\mathrm{g} / \mathrm{L}: \mathrm{Ca}\left(\mathrm{NO}_{3}\right)_{2}\right.$. $4 \mathrm{H}_{2} \mathrm{O}-1.18, \mathrm{KNO}_{3}-0.5, \mathrm{KH}_{2} \mathrm{PO}_{4}-0.136, \mathrm{MgSO}_{4} \cdot 7 \mathrm{H}_{2} \mathrm{O}-0.48$ ) to obtain a concentration of $5 \cdot 10^{4}$ macroconidia/mL. Some of the suspension was left for control. P. fluorescens cells washed off the medium were added to the remaining part of the suspension to reach a concentration of $5 \times 10^{6}$ cells $/ \mathrm{mL}$. Macroconidia were incubated for $6 \mathrm{~h}$ at $24^{\circ} \mathrm{C}$. We microscopically examined 300 macroconidia in each case and registered the proportion of germinated macroconidia from the total number of examined ones. We also measured the length of growth tubes.

\subsection{Chromatographic Analysis of Low-Molecular-Weight Components of Root Exudates}

The quantitative composition of sugars, organic acids, and amino acids in the collected exudates was evaluated using a Waters ACQUITY UPLC H-Class Ultra Productive Liquid Chromatography (UPLC) system (Waters, USA). The analyses were repeated three times. Solutions of root exudates were filtered under vacuum through $0.45 \mu \mathrm{m}$ membrane filters and concentrated at $45^{\circ} \mathrm{C}$ on rotary vacuum evaporator Heidolph Hei-VAP Precision (Heidolph Instruments GMBH \& CO KG, Germany) to a volume of $10 \mathrm{~mL}$. Concentrates were passed through a DOWEX 50WX8 100-200 mesh ion exchange resin in hydrogen form (Sigma-Aldrich, Co.) for separation into two fractions: (1) organic acids and sugars, (2) amino acids. The resulting fractions were evaporated to dryness under vacuum and dissolved in $1 \mathrm{~mL}$ of Milli-Q water.

Organic acids were separated in 10mM orthophosphoric acid on a Waters ACQUITY CSH C18 $(1.7 \mu \mathrm{m}, 2.1 \times 75 \mathrm{~mm})$ column (Waters, CIIIA) at flow rate $0.1 \mathrm{~mL} / \mathrm{min}$, column temperature $24^{\circ} \mathrm{C}$ and detected on Waters eXPDA detector at a wavelength of $220 \mathrm{~nm}$.

Sugars were determined by refractometry using a Waters 2414 detector included in the UPLC system. The analysis was performed using the SUPELCOSIL LC-NH2 (5 $\mu \mathrm{m}, 4.6 \times 250 \mathrm{~mm})$ column (Sigma-Aldrich, Co.) with $75 \%$ acetonitrile at flow rate $1 \mathrm{~mL} / \mathrm{min}$ and column temperature $31^{\circ} \mathrm{C}$.

To determine the composition of proteinogenic amino acids except L-tryptophan, we used fluorescent derivatives of amino acids obtained and analyzed according to the protocol for the Waters AccQ-Tag method (Waters, USA). L-tryptophan was analyzed without derivatization by separation on Waters ACQUITY UPLC BEH RP18 Shield $(1.7 \mu \mathrm{m}, 2.1 \times 50 \mathrm{~mm})$ column (Waters, CIIIA) in mixture of $0.1 \%$ formic acid (A) and acetonitrile supplied with $0.1 \%$ formic acid (B) with gradient at flow rate $0.3 \mathrm{~mL} / \mathrm{min}$ from 1 to $18 \% \mathrm{~B}$ for 5 minutes, followed by washing with $80 \%$ B for 2 minutes and conditioning the column for 3 minutes at 1\% B. L-tryptophan was detected with fluorescence detector $\left(\lambda_{\mathrm{ex}}=280 \mathrm{~nm}, \lambda_{\mathrm{em}}=350 \mathrm{~nm}\right)$.

\subsection{Statistical Data Analysis}

One-way ANOVA and Student's t-test were used to compare the number of germ tubes $(n=600)$ with a certain orientation; the length of germ tubes $(n=300)$; the quantitative composition of sugars, organic acids and amino acids in root exudates of control barley, barley colonized by the bacterium $(n=4)$ and barley colonized jointly by the fungus and the bacterium $(n=8)$. Values given in tables are means \pm standard deviations. Error bars in diagrams show standard deviation. Significant differences in germination of macroconidia were analyzed using the Mann-Whitney U-test. Values with different letters are significantly different at $p \leq 0.05$ when applying Fisher's LSD test and at $p \leq 0.01$ when applying Mann-Whitney U-test.

Author Contributions: N.V. designed the experiment, analyzed the data and contributed to the writing of the manuscript; V.S. tested chemotropism in F. culmorum, assessed the influence of exudates on F. culmorum growth and edited the manuscript; A.S. carried out chromatographic analysis of root exudates and edited the manuscript; 
O.S. conceived and designed the research, wrote the manuscript and carried out an overall supervision of the research. All the authors read and approved the final version of the manuscript.

Funding: The work related to the cultivation of plants and microorganisms was supported by the Russian Foundation for Basic Research (grant 18-016-00111), chromatographic analysis of amino acids in root exudates was supported by the Russian Science Foundation (grant 19-16-00097).

Acknowledgments: The authors are grateful to Elena Borodina, engineer of All-Russia Research Institute for Agricultural Microbiology, for technical support. We thank three anonymous reviewers for a thorough analysis of the manuscript and valuable critical remarks.

Conflicts of Interest: The authors declare no conflict of interest.

\section{Abbreviations}

$\begin{array}{ll}\text { CDA } & \text { Czapek-Dox agar } \\ \text { CDB } & \text { Czapek-Dox broth } \\ \text { UPLC } & \text { ultra performance liquid chromatography } \\ \text { ACA } & \text { aromatic carboxylic acids } \\ \text { DW } & \text { Dry Weight }\end{array}$

\section{References}

1. Cook, R.J.; Baker, K.F. The Nature and Practice of Biological Control of Plant Pathogens, 2nd ed.; APS Press: St. Paul, MN, USA, 1983; p. 539.

2. Parry, D.W.; Jenkinson, P.; McLeod, L. Fusarium ear blight (scab) in small grain cereals—A review. Plant Pathol. 1995, 44, 207-238. [CrossRef]

3. McMullen, M.; Jones, R.; Gallenberg, D. Scab of wheat and barley: A re-emerging disease of devastating impact. Plant Dis. 1997, 81, 1340-1348. [CrossRef]

4. Beccari, G.; Covarelli, L.; Nicholson, P. Infection processes and soft wheat response to root rot and crown rot caused by Fusarium culmorum. Plant Pathol. 2011, 60, 671-684. [CrossRef]

5. Covarelli, L.; Beccari, G.; Steed, A.; Nicholson, P. Colonization of soft wheat following infection of the stem base by Fusarium culmorum and translocation of deoxynivalenol to the head. Plant Pathol. 2012, 61, 1121-1129. [CrossRef]

6. Becher, R.; Miedaner, T.; Wirsel, S.G.R. Biology, diversity, and management of FHB-causing Fusarium species in small-grain cereals. In The Mycota XI, Agricultural Applications, 2nd ed.; Kempken, F., Ed.; Springer: Berlin/Heidelberg, Germany, 2013; Volume 11, pp. 199-241.

7. Scherm, B.; Balmas, V.; Spanu, F.; Pani, G.; Delogu, G.; Pasquali, M.; Migheli, Q. Fusarium culmorum: Causal agent of foot and root rot and head blight on wheat. Mol. Plant Pathol. 2013, 14, 323-341. [CrossRef] [PubMed]

8. Mesterhazy, A. Role of deoxynivalenol in aggressiveness of Fusarium graminearum and F. culmorum and in resistance to Fusarium head blight. Eur. J. Plant Pathol. 2002, 108, 675-684. [CrossRef]

9. Wagacha, J.M.; Muthomi, J.W. Fusarium culmorum: Infection process, mechanisms of mycotoxin production and their role in pathogenesis in wheat. Crop. Prot. 2007, 26, 877-885. [CrossRef]

10. Winter, M.; Koopmann, B.; Döll, K.; Karlovsky, P.; Kropf, U.; Schlüter, K.; von Tiedemann, A. Mechanisms regulating grain contamination with trichothecenes translocated from the stem base of wheat (Triticum aestivum) infected with Fusarium culmorum. Phytopathology 2013, 103, 682-689. [CrossRef] [PubMed]

11. Rocha, O.; Ansari, K.; Doohan, F.M. Effects of trichothecene mycotoxins on eukaryotic cells: A review. Food Addit. Contam. 2005, 22, 369-378. [CrossRef] [PubMed]

12. Bensassi, F.; Gallerne, C.; El Dein, O.S.; Lemaire, C.; Hajlaoui, M.R.; Bacha, H. Involvement of mitochondria-mediated apoptosis in deoxynivalenol cytotoxicity. Food Chem. Toxicol. 2012, 50, 1680-1689. [CrossRef]

13. Weller, D.M.; Landa, B.B.; Mavrodi, O.V.; Schroeder, L.K.; De la Fuente, L.; Blouin Bankhead, S.; Allende Molar, R.; Bonsall, R.F.; Mavrodi, D.V.; Thomashow, L.S. Role of 2,4-diacetylphloroglucinol-producing fluorescent Pseudomonas spp. in the defense of plant roots. Plant Biol. 2007, 9, 4-20. [CrossRef] [PubMed]

14. Lugtenberg, B.; Kamilova, F. Plant-growth-promoting Rhizobacteria. Annu. Rev. Microbiol. 2009, 63, 541-556. [CrossRef] [PubMed] 
15. Raaijmakers, J.M.; de Bruijn, I.; de Kock, M.J.D. Cyclic lipopeptide production by plant-associated Pseudomonas species: Diversity, activity, biosynthesis and regulation. Mol. Plant Microb. Interact. 2006, 19, 699-710. [CrossRef] [PubMed]

16. Compant, S.; Clement, C.; Sessitsch, A. Plant growth-promoting bacteria in the rhizo-and endosphere of plants: Their role, colonization, mechanisms involved and prospects for utilization. Soil Biol. Biochem. 2010, 42, 669-678. [CrossRef]

17. Strunnikova, O.K.; Shakhnazarova, V.Y.; Vishnevskaya, N.A.; Chebotar, V.K.; Tikhonovich, I.A. Development and relations of Fusarium culmorum and Pseudomonas fluorescens in soil. Microbiology 2007, 76, 596-602. [CrossRef]

18. Strunnikova, O.K.; Shakhnazarova, V.Y.; Vishnevskaya, N.A.; Chebotar, V.K.; Tikhonovich, I.A. Interactions between Fusarium culmorum and Pseudomonas fluorescens in the rhizosphere and rhizoplane of barley. Mycol. Phytopathol. 2008, 42, 70-77.

19. Strunnikova, O.K.; Vishnevskaya, N.A.; Tikhonovich, I.A. Colonization of barley roots by Fusarium culmorum and influence of Pseudomonas fluorescens on the process. Microbiology 2010, 79, 865-870. [CrossRef]

20. Strunnikova, O.K.; Vishnevskaya, N.A.; Ruchiy, A.S.; Shakhnazarova, V.Y.; Vorobyov, N.I.; Chebotar, V.K. The influence of soils with different textures on development, colonization capacity and interactions between Fusarium culmorum and Pseudomonas fluorescens in soil and on barley roots. Plant Soil 2015, 389, 131-144. [CrossRef]

21. De Weert, S.; Vermeiren, H.; Mulders, I.H.M.; Kuiper, I.; Hendrickx, N.; Bloemberg, G.V.; Vanderleyden, J.; De Mot, R.; Lugtenberg, B.J.J. Flagella-driven chemotaxis towards exudate components is an important trait for tomato root colonization by Pseudomonas fluorescens. Mol. Plant Microb. Interact. 2002, 15, 1173-1180. [CrossRef]

22. Rudrappa, T.; Czymmek, K.J.; Pare, P.W.; Bais, H.P. Root-secreted malic acid recruits beneficial soil bacteria. Plant Physiol. 2008, 148, 1547-1556. [CrossRef]

23. Ling, N.; Raza, W.; Ma, J.; Huang, Q.; Shen, Q. Identification and role of organic acids in watermelon root exudates for recruiting Paenibacillus polymyxa SQR-21 in the rhizosphere. Eur. J. Soil Biol. 2011, 47, 374-379. [CrossRef]

24. Neal, A.L.; Ahmad, S.; Gordon-Weeks, R.; Ton, J. Benzoxazinoids in root exudates of maize attract Pseudomonas putida to the rhizosphere. PLoS ONE 2012, 4, e35498. [CrossRef] [PubMed]

25. Tan, S.; Yang, C.; Mei, X.; Shen, S.; Raza, W.; Shen, Q.; Xu, Y. The effect of organic acids from tomato root exudates on rhizosphere colonization of Bacillus amyloliquefaciens T-5. Appl. Soil Ecol. 2013, 64, 15-22. [CrossRef]

26. Zhang, N.; Wang, D.; Liu, Y.; Li, S.; Shen, Q.; Zhang, R. Effects of different plant root exudates and their organic acid components on chemotaxis, biofilm formation and colonization by beneficial rhizosphere-associated bacterial strains. Plant Soil 2013, 374, 689-700. [CrossRef]

27. Turrà, D.; El Ghalid, M.; Rossi, F.; Di Pietro, A. Fungal pathogen uses sex pheromone receptor for chemotropic sensing of host plant signals. Nature 2015, 527, 521-524. [CrossRef] [PubMed]

28. Lombardi, N.; Vitale, S.; Turrà, D.; Reverberi, M.; Fanelli, C.; Vinale, F.; Marra, R.; Ruocco, M.; Pascale, A.; d'Errico, G.; et al. Root exudates of stressed plants stimulate and attract Trichoderma soil fungi. MPMI 2018, 31, 982-994. [CrossRef]

29. Shaposhnikov, A.I.; Vishnevskaya, N.A.; Shakhnazarova, V.Y.; Belimov, A.A.; Strunnikova, O.K. The role of barley root exudates as nutrition source in the interactions between Fusarium culmorum and Pseudomonas fluorescens. Mycol. Phytopathol. 2019, 53, 301-308.

30. Akhter, A.; Hage-Ahmed, K.; Soja, G.; Steinkellner, S. Potential of Fusarium wilt-inducing chlamydospores in vitro behaviour in root exudates and physiology of tomato in biochar and compost amended soil. Plant Soil 2016, 406, 425-440. [CrossRef]

31. Kamilova, F.; Lamers, G.; Lugtenberg, B. Biocontrol strain Pseudomonas fluorescens WCS365 inhibits germination of Fusarium oxysporum spores in tomato root exudates as well as subsequent formation of new spores. Environ. Microbiol. 2008, 10, 2455-2461. [CrossRef] [PubMed]

32. Steinkellner, S.; Mammerler, R.; Vierheilig, H. Microconidia germination of the tomato pathogen Fusarium oxysporum in the presence of root exudates. J. Plant Interact. 2005, 1, 23-30. [CrossRef] 
33. Steinkellner, S.; Mammerler, R.; Vierheilig, H. Germination of Fusarium oxysporum in root exudates from tomato plants challenged with different Fusarium oxysporum strains. Eur. J. Plant Pathol. 2008, 122, 395-401. [CrossRef]

34. Li, X.G.; Wei, Q.; Liu, B.; Alam, M.S.; Wang, X.X.; Shen, W.; Han, Z.M. Root exudates of transgenic cotton and their effects on Fusarium oxysporum. Front. Biosci. 2013, 18, 725-733. [CrossRef] [PubMed]

35. Shaposhnikov, A.I.; Shakhnazarova, V.Y.; Vishnevskaya, N.A.; Borodina, E.V.; Strunnikova, O.K. Aromatic carboxylic acids in root exudates of barley and their influence on growth of Fusarium culmorum and Pseudomonas fluorescens. Appl. Biochem. Microbiol. 2020, 56, 1-9.

36. Bais, H.P.; Weir, T.L.; Perry, L.G.; Gilroy, S.; Vivanco, J.M. The role of root exudates in rhizosphere interactions with plants and other organisms. Ann. Rev. Plant Biol. 2006, 57, 233-266. [CrossRef]

37. Kamilova, F.; Kravchenko, L.V.; Shaposhnikov, A.I.; Makarova, N.; Lugtenberg, B. Effects of the tomato pathogen Fusarium oxysporum $f$. sp radicis-lycopersici and of the biocontrol bacterium Pseudomonas fluorescens WCS365 on the composition of organic acids and sugars in tomato root exudate. Mol. Plant-Microb. Interact. 2006, 19, 1121-1126. [CrossRef]

38. Kamilova, F.; Kravchenko, L.V.; Shaposhnikov, A.I.; Azarova, T.; Makarova, N.; Lugtenberg, B. Organic acids, sugars, and Ltryptophane in exudates of vegetables growing on stonewool and their effects on activities of rhizosphere bacteria. Mol. Plant-Microb. Interact. 2006, 19, 250-256. [CrossRef]

39. Strunnikova, O.K.; Feoktistova, A.S.; Vishnevskaya, N.A.; Chebotar, V.K. Role competition between Pseudomonas fluorescens 2137GUS and Fusarium culmorum for colonization of barley roots. Mycol. Phytopathol. 2011, 45, 362-369.

40. Jones, D.L.; Darrah, P.R. Re-sorption of organic-compounds by roots of Zea mays L. and its consequences in the rhizosphere. 2. Experimental and model evidence for simultaneous exudation and re-sorption of soluble C compounds. Plant Soil 1993, 153, 47-59. [CrossRef]

41. Jones, D.L.; Darrah, P.R. Amino-acid influx at the soil-root interface of Zea mays L. and its implications in the rhizosphere. Plant Soil 1994, 163, 1-12. [CrossRef]

42. Jones, D.L.; Nguyen, C.; Finlay, R.D. Carbon flow in the rhizosphere: Carbon trading at the soil-root interface. Plant Soil 2009, 321, 5-33. [CrossRef]

43. Phillips, D.A.; Fox, T.C.; King, M.D.; Bhuvaneswari, T.V.; Teuber, L.R. Microbial products trigger amino acid exudation from plant roots. Plant Physiol. 2004, 136, 2887-2894. [CrossRef]

44. King, E.O.; Ward, M.K.; Raney, D.E. Two simple media for the demonstration of pyocyanin and fluorescein. J. Lab. Clin. Med. 1954, 44, 301-307. 